\section{Volatile Fruit Constituents of Theobroma grandiflorum}

\author{
Christian Cabral Velho, Denys J. Charles, and James E. Simon \\ Department of Horticulture, Purdue University, West Lafayette, IN 47907
}

Additional index words. cupuassu, essential oils, new fruit crop

Cupuassu [Theobroma grandiflorum (Wind ex Spreng) Schum, Sterculiaceae], a close relative of cacao ( $T$. cacao L.), is a promising new fruit crop from Brazil (Cabral Velho et al., 1990). The unusual and strongly aromatic fruit contains a highly flavored pulp (technically an aril) that can impart a new flavor to many food products including juices, ice creams, yogurts, liquors, wine, syrups, and jellies (Arkcoll and Clement, 1989; Vasconcelos et al., 1975). The seeds can also be used to make chocolate (Vasconcelos et al., 1975), and oil extracted from the seeds may be of economic value (Arkcoll and Clement, 1989).

The cupuassu tree is native to the Amazonian, Maranhao, and Para regions of Brazil, the only places where the fruits are commercially processed and consumed. Fruits are harvested from wild trees (Calzavara et al., 1984) and the plant has not yet been brought under cultivation. The fruits are oblong, 12 to $25 \mathrm{~cm}$ long, 10 to $12 \mathrm{~cm}$ in diameter, and weigh 1 to $2 \mathrm{~kg}$. Each fruit contains $\approx 50$ seeds that are surrounded by a mucilaginous pulp that has an acid taste and a strong aroma (Chaar, 1980).

The nonvolatile constituents of cupuassu pulp including soluble solids $\left(10.5^{\circ}\right.$ Brix $)$ brix : acid ratio (4.47), reducing sugars, and

Received for publication 20 Sept. 1990. Journal Paper no. 12,685, Purdue Univ. Agr. Expt. Sta., West Lafayette, IN 47907. We thank Giorgine Venturieri, INPA/Manaus, Brazil, for providing the cupuassu fruits, and Edward Tigchelaar, Purdue Univ., for bringing the fruits to us from Brazil. The cost of publishing this paper was defrayed in part by the payment of page charges. Under postal regulations, this paper therefore must be hereby marked advertisment solely to indicate this fact. nonreducing sugars have been reported (Chaar, 1980). We now report on the major volatile components of cupuassu fruit.

Two mature fruits of cupuassu purchased on the market were immediately air-shipped at room temperature and hand-delivered from INPA/Manaus (Brazil) on 3 Aug. 1989 to our laboratory. Fruits were cut in half, the rind discarded, and the seeds removed from the pulp by use of a scalpel. The fresh pulp and seeds were analyzed separately. Volatile components were extracted as described by Charles and Simon (1990), except that dichloromethane was used instead of hexane. Volatile composition was determined using a Varian $3700 \mathrm{GC}$ and 4270 integrator, and confirmed by a Finnigan 4000 GC/MS, as previously described (Charles and Simon, 1990).

All but three volatiles in the pulp also were found in the seeds (Table 1). The major volatiles in the pulp (9-octadecanoic acid, hexadecanoic acid, and piperazine) were also present in relatively large amounts in the seeds in cacao (Gill et al., 1984). The major volatile in the seeds, benzene acetaldehyde $(30.4 \%)$, was absent in the pulp.

Eleven volatile constituents (including all compounds $\approx 0.02 \%$ ) were identified in cupuassu fruit. These included 10 compounds from the pulp and eight from the seeds. As many of these compounds are aromatic volatiles, some commonly used in the flavor industry (Heath, 1981), they may play an important role in the aroma of the cupuassu fruit.

\section{Literature Cited}

Arkcoll, D.B. and C.R. Clement. 1989. Potential new food crops from the Amazon, p. 150-165. In: G.E. Wickens, N. Haq, and P. Day (eds.). (Table 1). Hexadecanoic acid was also found
Table 1. Composition of volatile constituents from the pulp and seeds of Theobroma grandiflorum.

\begin{tabular}{|c|c|c|}
\hline \multirow{2}{*}{$\begin{array}{l}\text { Volatile } \\
\text { constituents }^{2}\end{array}$} & \multicolumn{2}{|c|}{$\begin{array}{l}\text { Volatile composition } \\
\text { by fruit part (percent } \\
\text { of total volatiles) }\end{array}$} \\
\hline & Pulp & Seeds \\
\hline 3 Methyl-2-heptanol & 0.02 & $\cdots$ \\
\hline Acetoin $y$ & 0.1 & -- \\
\hline 1,3-Butanediol & 0.02 & -- \\
\hline Dodecanaly & 4.2 & 0.3 \\
\hline Benzeneethanol & 0.5 & 2.2 \\
\hline Piperazine & 18.6 & 8.5 \\
\hline Hexadecanoic acidy & 19.4 & 6.3 \\
\hline \multicolumn{3}{|c|}{ Undecanoic acid, 2,8-dimethyl-, } \\
\hline methyl ester $\mathbf{x}$ & 1.9 & 8.3 \\
\hline 9-Octadecanoic acid $\mathbf{x}$ & 24.4 & 11.1 \\
\hline Decyl cyclohexane & 4.6 & 4.0 \\
\hline Benzene acetaldehyde & -- & 30.4 \\
\hline
\end{tabular}

${ }^{2}$ Listed in order of elution.

${ }^{y}$ Common organic chemicals used in flavoring (Heath, 1981).

Common flavoring ingredients classified as GRAS (Heath, 1981).

New crops for food and industry. Chapman and Hall, New York.

Cabral Velho, C., A. Whipkey, and J. Janick. 1990. Cupuassu (Theobroma grandiflorum): a new beverage crop for Brazil, p. 372-375. In: J. Janick and J.E. Simon (eds.). Advances in new crops. Timber Press, Portland, Ore.

Calzavara, B. B. G., C.H. Muller, and O. Kabwage. 1984. Fruticultura tropical: o cupuacuzeiro. Belem, EMBRAPA/CPATU. Documents 32.

Chaar, J.M. 1980. Composicao do cupuacu (Theobroma grandiflorum (Schum) e conservacao do seu nectar por meios fisicos e quimicos. MS Thesis, UFRRJ, Rio de Janeiro, Brazil.

Charles, D.J. and J.E. Simon. 1990. Comparison of extraction methods for the rapid determination of essential oil content and composition of basil (Ocimum spp.). J. Amer. Soc. Hort. Sci. 115(3):458-462.

Gill, M. S., A.J. MacLeod, and M. Moreau. 1984. Volatile components of cocoa with particular reference to glucosinolate products. Photochemistry 23(9): 1937-1942.

Heath, H.B. 1981. Source book of flavors. AVI, Westport, Corm. p. 332435.

Vasconcelos, M. N. Z., M. Leao da Silva, J.G. Soares Maia, and O.R. Gottlieb. 1975. Estudos quimicos das sementes do cupuacu. Acta Amazonica 5 :293-295. 